\title{
The Role of Apoptotic Signaling in Axon Guidance
}

\author{
Riley Kellermeyer ${ }^{\dagger}$, Leah M. Heydman ${ }^{\dagger}$, Grant S. Mastick and Thomas Kidd *(D) \\ Department of Biology/MS 314, University of Nevada, 1664 N. Virginia St., Reno, NV 89557, USA; \\ rileykellermeyer@gmail.com (R.K.); leah.heydman@gmail.com (L.M.H.); gmastick@unr.edu (G.S.M.) \\ * Correspondence: tkidd@unr.edu; Tel.: +1-775-784-6669 \\ + These authors contributed equally to this work.
}

Received: 15 September 2018; Accepted: 16 October 2018; Published: 18 October 2018

\begin{abstract}
Navigating growth cones are exposed to multiple signals simultaneously and have to integrate competing cues into a coherent navigational response. Integration of guidance cues is traditionally thought to occur at the level of cytoskeletal dynamics. Drosophila studies indicate that cells exhibit a low level of continuous caspase protease activation, and that axon guidance cues can activate or suppress caspase activity. We base a model for axon guidance on these observations. By analogy with other systems in which caspase signaling has non-apoptotic functions, we propose that caspase signaling can either reinforce repulsion or negate attraction in response to external guidance cues by cleaving cytoskeletal proteins. Over the course of an entire trajectory, incorrectly navigating axons may pass the threshold for apoptosis and be eliminated, whereas axons making correct decisions will survive. These observations would also explain why neurotrophic factors can act as axon guidance cues and why axon guidance systems such as Slit/Robo signaling may act as tumor suppressors in cancer.
\end{abstract}

Keywords: axon guidance; growth cone; cytoskeleton; caspases; apoptosis; signal integration; basal level of caspase activity; death associated inhibitor of apoptosis; axon branching; Netrin; DCC; Frazzled; Slit; Robo; Drosophila

\section{Introduction}

The navigational center of growing axons is the growth cone, a highly dynamic expansion of the axon shaft that samples the environment and integrates multiple cues to generate directed extension, retraction, and turning [1,2]. Traditionally, axon attractants such as Netrins are thought to increase cytoskeletal outgrowth towards a cue, whereas axon repellents such as Slits inhibit cytoskeletal growth [3,4]. The net effect of attractive and repulsive cues on the cytoskeleton results in growth towards attractive cues and away from repulsive cues. Integration has been demonstrated to also occur through interactions between cell surface receptors, and through intracellular kinases $[5,6]$. More recent evidence suggests that the traditional view of growth cones navigating up or down gradients of guidance cues such as Netrin may not be accurate or even valid in vivo [7-11]. Our own work led us to identify a role for the apoptotic machinery in the growth cone that is likely functioning to integrate opposing guidance cues. This review examines models for how the cell death machinery could be involved in axon guidance with an emphasis on results from Drosophila.

\section{Drosophila Netrin-B Is a Neurotrophic Factor That Blocks Cell Death}

Netrins are diffusible axon guidance cues most famous for attracting axons to the CNS midline [12]. The fly has two Netrin genes, $N e t A$ and $N e t B$, that are required for midline and motor neuron axon guidance $[13,14]$. The genes appear to be the product of tandem duplication and display a high degree of functional overlap. Netrins are expressed by the CNS midline and embryos lacking both 
Netrins $(N e t A B)$ have axon guidance defects and increased cell death. Both phenotypes can be rescued by midline expression of either gene. Localized sources of Netrins therefore appear to provide a navigational cue. In contrast to midline expression, pan-neuronal expression of either Netrin in wild type embryos leads to axon phenotypes, either due to a lack of positional information specific to the midline or through attraction to non-midline areas $[13,14]$. It was therefore surprising to find that pan-neuronal expression of NetB alone can rescue axon guidance defects in NetAB embryos [15]. In contrast, pan-neural expression of Net $A$ increases the severity of the Net $A B$ mutant phenotype, establishing a clear difference between the proteins. NetB was subsequently identified as a neurotrophic factor when over-expressed, because blocking cell death using the baculovirus p35 caspase inhibitor in discrete subsets of neurons can rescue Net $A B$ midline guidance defects [15]. These findings substantiate a model for a non-apoptotic role for caspases in the growth cone, as suggested by prior results in Xenopus retinal growth cones and other systems [16-18].

\section{The Apoptotic Machinery and Guidance Receptors}

Programmed cell death or apoptosis is a key part in the development of multicellular organisms and in the maintenance of the correct number of cells in mature animals [27]. The classic role for cell death in neural development is to eliminate unneeded connections that fail to compete for a limiting survival factor, the neurotrophic hypothesis [28]. For example, axons that are misguided and fail to reach their target tissue die [29]. Further research has shown that neurotrophic factors can also induce death in certain contexts, and this activity is functionally conserved in the fly [30-32]. Apoptosis operates through molecular cascades, offering several potential signaling nodes that could intersect with axon guidance signaling pathways. A crucial event in apoptosis is the activation of specialized cysteine-aspartic acid proteases called caspases (Figure 1A). Signals derived from the mitochondria, in response to external pro-apoptotic signals or the withdrawal of trophic support molecules, trigger activation of initiator caspases [33-35]. Activation relies on multimerization and/or conformational changes of initiator caspases, like Dronc, leading to proteolytic activation of effector caspases such as Drice and Dcp-1. This amplification of effector caspases is then responsible for the extensive proteolytic cleavage that occurs during apoptosis. Caspase activity is buffered by the death-associated inhibitor of apoptosis protein family (Diap1/thread), the viral p35 protein and other specialized inhibitors which oppose caspase activation [36-41]. Many caspase inhibitors, like Diap1, are continuously active to prevent apoptosis by marking initiator caspases for degradation [42,43]. To initiate apoptosis, Diap1 is cleaved by inhibitor of apoptosis antagonists, notably Hid, Grim and Reaper (RHG proteins), ultimately allowing caspase activation [34]. In addition to apoptosis, caspases have been implicated in actin dynamics of Drosophila spermatid individualization [44,45], sense organ precursor selection [42,46], and dendrite retraction [47,48] (reviewed in [35]). Together, this cascade of apoptotic regulators is present in all cells at low levels, but normally kept in check by specific and tightly regulated modulators.

The apoptotic machinery is present in the growth cone of extending axons and can be activated by external signals such as Netrin [16]. The principal vertebrate Netrin receptor is DCC (Deleted in Colorectal Cancer; Frazzled in the fly), which dimerizes upon ligand binding to stimulate signaling pathways that alter cytoskeletal dynamics [12]. Netrins are also capable of repelling axons through the Unc-5 receptor [49]. In vertebrates, failure of DCC to homodimerize triggers cell death via the initiator caspase-9 and the effector caspase-3 [50]. The dual function of DCC to transduce both migratory and apoptotic signals is known as the dependence receptor hypothesis, wherein cell survival is dependent on ligand occupancy of receptors. Dependence receptors such as DCC are characterized by having caspase cleavage sites in their cytoplasmic domains and that the absence of the ligand triggers caspase cleavage of the receptor. The DCC caspase cleavage site is required to trigger apoptosis, and mutation of the site in mice prevents tumor suppression [51,52]. However, the ability of Netrin to act as a survival factor, particularly in spinal cord development is controversial as conflicting survival phenotypes 
have been observed by different groups $[53,54]$. Additional recent evidence strongly suggests that the dependence receptor mechanism is not operating in the mouse spinal cord [55].

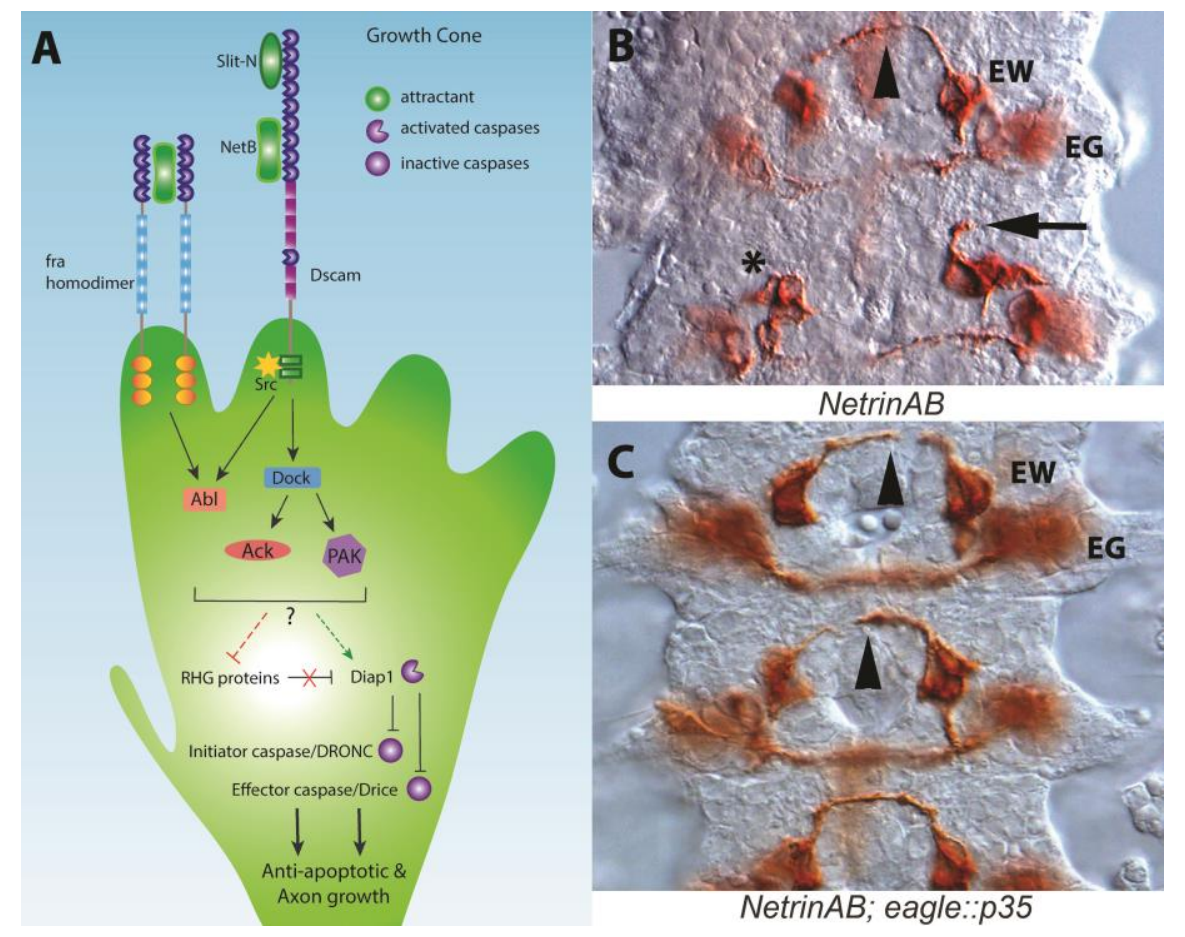

Figure 1. Apoptotic machinery and axons. (A) Schematic of axon guidance signaling pathways that potentially interact with the apoptotic machinery. Candidate downstream effectors are shown based on proteins that can promote survival and are known to interact with the receptors shown in Drosophila [19-24]. Cytoplasmic signaling components may act on caspase regulators, such as inactivating RHG proteins, promoting Diap1 function or could act directly on the caspases (uncertainty indicated by dotted lines). (B) A Drosophila embryo lacking the Netrin-A and Netrin-B axon guidance genes (NetAB) stained to reveal eagle positive axons (brown). Anterior is to the top. The EW and EG neuron clusters are indicated. In Net $A B$ mutants, the EW commissure successfully crosses the midline about $50 \%$ of the time (arrowhead). A growth cone can be seen remaining projecting ipsilaterally (arrow). An EW cluster lacking a leading growth cone either due to developmental delay or apoptosis of a neuron can also be seen (asterisk). An overall lack of symmetry of the EW and EG cluster can be seen with the clusters mispositioned and differences in neuron number reflected in differences in staining intensity. The EG commissures are present but not in the plane of focus. (C) A Drosophila Net $A B$ embryo whose axon guidance defects have been rescued by expression of the p35 effector caspase inhibitor $[25,26]$. Growth cones of the EW neuron cluster can be seen crossing the midline (arrowheads), while the growth cones of the contralateral homologues are growing at a slower rate. The growth cones of the most posterior segment in this panel have fasciculated with the contralateral homologue even though the more anterior segments are slightly older in development. In older embryos $90 \%$ of the EW axons cross the midline. Images courtesy of G. Newquist.

In flies, the DCC homologue, frazzled (fra; also called Unc-40 in C. elegans), lacks the caspase cleavage site in the cytoplasmic domain, suggesting Fra is not a dependence receptor, though alternative sites could exist [54,56]. Additionally, the loss of fra activity triggers apoptosis in some tissues, rather than being protective from cell death, as would be expected from the loss of a dependence receptor [57]. The ability to rescue the axon guidance defects of Net $A B$ mutants by blocking apoptotic signaling therefore requires an alternative explanation to the dependence receptor hypothesis. 


\section{How Could Caspase Signaling Operate in Growth Cone Guidance?}

Apoptosis requires major changes in the structure of cells via rearrangements of the cytoskeleton, so it is not surprising that caspases cleave a large number of cytoskeletal and structural proteins such as actin, alpha-tubulin, and Spectrin [58-61]. Caspase-3 cleaves Spectrin in growth cones in culture [62]. Changes in levels and localization of cytoskeletal proteins are observed during apoptosis of larval salivary glands, and these changes are prevented by inhibiting caspases [63]. Many proteins that modulate the cytoskeleton are also cleaved during apoptosis such as cofilin, GAP43, and rho kinase (Rock), as well as many cell adhesion molecules [64-66]. These molecules could serve as caspase substrates in the growth cone and their cleavage would likely decrease protrusion (actin driven extension of filopodia and lamellipodia) and inhibit axon outgrowth. Inhibiting caspase activity would protect cytoskeletal components from proteolysis and potentially increase protrusion and forward movement. Migrating border cells in the Drosophila ovary provide an apoptosis-independent example for this model. Normal border cell migration requires the activity of the Diap1 caspase inhibitor [67]. Diap1 forms a complex with the actin cytoskeletal modulators Rac and Profilin, and Diap1 protects these modulators from degradation by Dronc. In ovary border cell migration, Diap1 alters cytoskeletal dynamics independent of apoptosis inhibition, as loss of Diap1 in these cells does not result in cell death and migration phenotypes are not rescued with p35. Similarly, Diap1 promotes F-actin assembly in polarized elongation of sensory organ progenitors by blocking Dronc activation, in a caspase-dependent, apoptosis-independent manner [68,69]. F-actin turnover at the cell margin therefore requires inhibition of Diap1 without any effect on cell survival. An additional example of non-apoptotic functions of caspases comes from the study of so-called "undead" cells in which Hid expression activates apoptosis, but the cells are kept alive by co-expression of p35 [70]. When these cells are created in the anterior-posterior boundary of the wing disc, the undead cells invade and migrate into the posterior domain of the wing disc. This migration is dependent on effector caspases and appears to require intermediate levels of caspase activity [71,72]. Comparable approaches have been taken in vertebrate neurons to separate axon growth from neuronal survival. Blocking cell death through over-expression of Bcl-2 or loss of Bax function was used to demonstrate that axon growth does not appear to be constitutive but likely relies on external signals [73,74].

There are several important implications from these and other studies for non-apoptotic functions of caspase protease activity. The first is that activation of the apoptotic machinery does not necessarily lead to cell death. In vertebrates, molecular mechanisms have been identified that prevent complete activation of the apoptotic cascade [75]. Studies of the synapse suggest that transient and local activation of caspases can remodel the synapse [76], and observations of activated caspase-3 restricted to the growth cone and sites of axon branching are consistent with this model [16,77]. Second, Drosophila studies have demonstrated that there is a continuous low level of initiator caspase activation through auto-processing and the role of Diap1 is to counteract this basal caspase activity [43,78-81]. Low levels of caspase activation have been visualized in wing discs using the FRET-based SCAT3 caspase activity probe [42]. A vertebrate Diap1 homologue, X-linked inhibitor of apoptosis (XIAP) plays a role in limiting caspase activation [82,83], and appears central to restricting caspase activation to subcellular compartments of neurons [84].

Returning to the fly CNS and the observation that Netrin mutant phenotypes can be rescued by anti-apoptotic factors, the simplest model to explain the effects of caspase inhibition in Netrin mutants is that there is a basal level of caspase activation in growth cones that has to be overcome for maximal forward growth (Figure 2A). This model was first proposed by Gilman and Mattson, after demonstrating that addition of caspase inhibitors to neuronal cultures increases axon outgrowth [76]. The implication is that a basal level of caspase proteolysis keeps normal axon growth below maximum levels, although the molecular targets of caspases in growth cones remain undefined. To support any of the models described, cleavage of specific substrates, such as cytoskeletal components, will have to be demonstrated in the growth cone itself, which may require the study of larger growth cones from other invertebrate or vertebrate species, given the small size of Drosophila growth cones. 


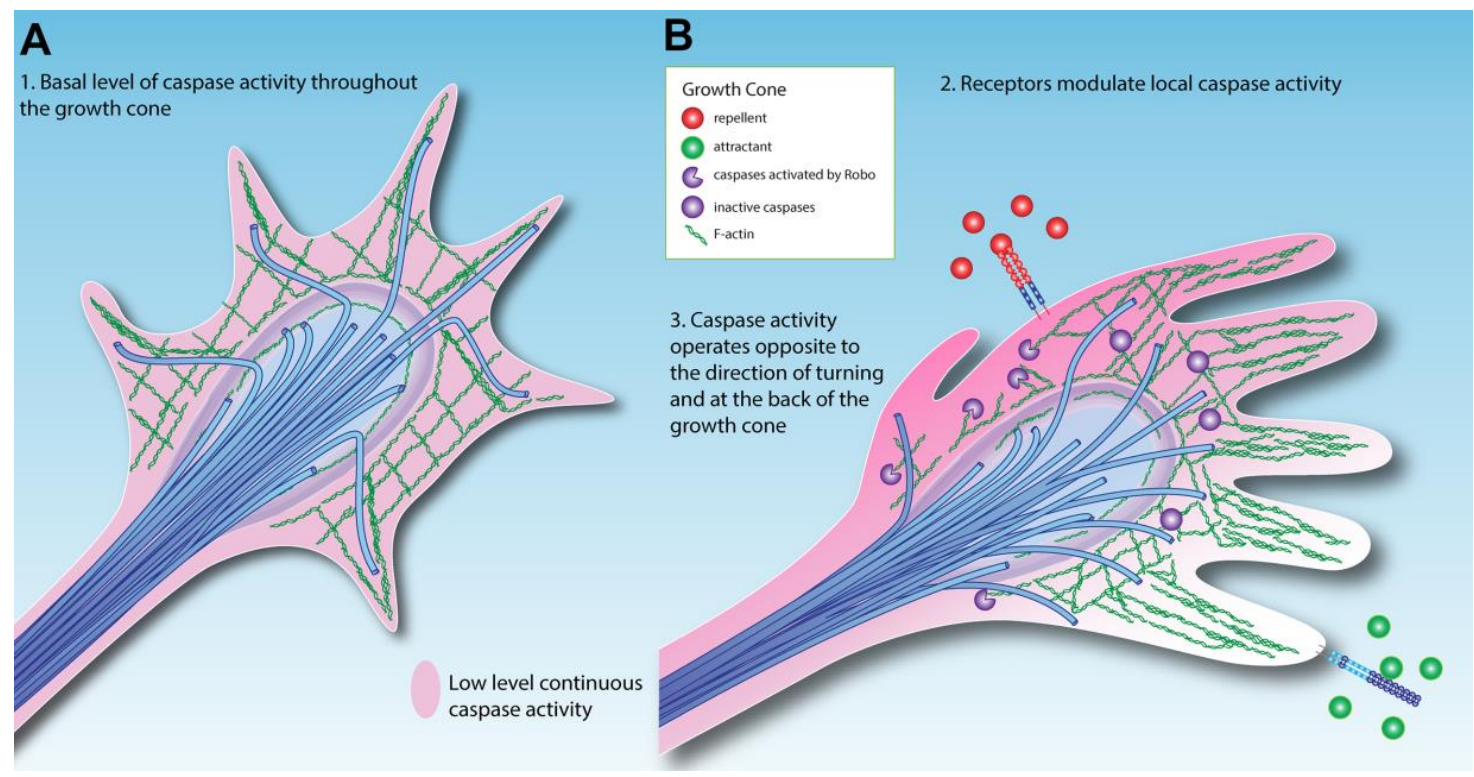

Figure 2. Model for caspase activity in the growth cone. (A) Simple low-level activation of caspases throughout the growth cone. (B) Attractant and repellent cues modulate caspase activity via cell surface receptors, altering the growth cone trajectory. In this model, repellents increase caspase activity, while attractants decrease caspase activity.

It is worth noting that caspases can also modulate the actin cytoskeleton independently of their protease roles, such as promoting Aip1/cofilin mediated actin polymerization in migrating lymphocytes, though it is not known how widespread this effect is [65].

\section{Extracellular Modulation of Caspase Activity in the Growth Cone}

An exciting possibility arising from this simple model of caspase-mediated guidance is that caspase activity could be actively modulated in response to external cues (Figure 2B). Mehlen has proposed that axon guidance signaling pathways actively modulate tumor cell survival, explaining why axon guidance molecules are implicated in preventing cancer [85]. Despite a large number of studies implicating Slit/Robo signaling as tumor suppressors in cancer, a direct link of Slit/Robo signals to apoptosis has not yet been shown [86]. In fly screens, the post-translational regulator of Robo, commissureless and its paralogue comm3, have been shown to suppress apoptotic phenotypes through unidentified mechanisms [87]. DCC has been strongly linked to caspase activity [50], and DCC acts as a tumor suppressor via its dependence receptor activity [52]. In flies, the Netrin receptor frazzled appears to act as a tumor suppressor, because while fra mutant clones are usually not viable, they can be rescued with p35 expression blocking cell death [57]. Additionally, loss of fra activity leads to invasive cell phenotypes reminiscent of metastasis [57,88]. Mutant clones of fra have not been made in the embryo, but fra homozygotes do not display increased cell death in the developing CNS [15]. This could reflect a tissue-specific difference between the embryo and eye-antennal discs, perhaps due to functional overlap between survival factors in the embryo. Alternatively, the differences between homozygous embryos and mutant clones could be the result of cell competition in which mutant clones are less fit than neighboring cells, a process that interestingly can involve Slit/Robo signaling [89]. In the embryo, NetB likely promotes axon growth by inhibiting caspase activity in the growth cone. Double mutants for the fra and Dscam 1 Netrin receptors display an increase in cell death, whereas there is no change in either mutant alone [15], suggesting multiple receptors may mediate this activity.

Emerging evidence reveals that repellent signaling pathways are able to activate caspases, in some cases through direct binding. The Slit/Robo, Eph/Ephrin and Sema/Plexin pathways all recruit and/or activate caspases $[17,77,90-94]$. Slit/Robo signaling in zebrafish axons has been shown to genetically 
interact with caspases, in a manner that suggests localized activation [77]. Consistent with Slit/Robo regulation of caspases, we have observed low levels of activated caspase in a pattern that matches Robo localization in the ventral nerve cord (Figure 3). This suggests that caspase activity in the growth cone is increased by axon repellents and decreased by attractants, allowing axon outgrowth in the direction of attractant cues (Figure 2B). Drosophila motor neurons similarly integrate information concerning the levels of attractants and repellents emanating from their target muscle [95]. Thus caspase activation and inhibition could sum the input signals to determine lowered caspase activity domains where forward growth occurs, while a widespread basal level of inhibitors like Diap1 restrict the spread of local caspase activation by repellents. In this respect, the model resembles the synapse where the duration and intensity of caspase activation determines the difference between synaptic remodeling and neuronal death $[96,97]$.

Dendritic pruning also requires localized caspase activation but over a much larger subcellular area (dendritic trees can be quite extensive compared to a growth cone), ultimately leading to the degradation of dendrites. Pruning relies heavily on the activation of initiator caspases such as Dronc [47,48]. Expression of p35, which blocks effector caspases, is either ineffective at blocking pruning [47], or only appears to delay pruning [98]. Migration of undead cells also requires initiator but not effector caspase activity, as migration is blocked when Diap1 is expressed (Diap1 inhibits both initiator and effector caspases) [71]. A distinguishing feature of non-apoptotic caspase activity may be a reliance on initiator caspases. Blocking cell death upstream of all caspases in fly embryos has remarkably little effect on the CNS axon scaffold [99], suggesting that caspase activity is dispensable for normal development. However, in sensitized backgrounds such as NetAB mutants, blocking effector caspases is sufficient to rescue axon guidance [15]. Overall these results suggest that there may be quantitatively different levels of caspase activation. Growth cones and migrating cells may display low continuous levels of caspase activation. Higher levels may be required for neuronal remodeling events in which structures or parts of the cell such as dendrites are lost, and the highest levels will of course lead to apoptosis. A mechanism for different levels of caspase activation has been proposed from observations of dendritic pruning. The model proposes that there is a threshold for cell death and that, below this threshold, IAPs bound to caspases can be quickly released without activation of the apoptosome [100]. This may represent a general mechanism for non-apoptotic functions of caspases but may need further refinement to account for multiple levels of caspase activation.

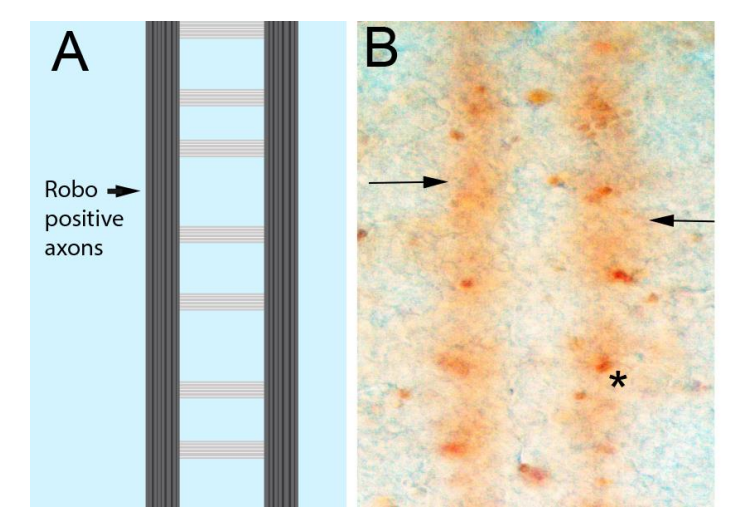

Figure 3. Low-level caspase activity in longitudinal axons. (A) Schematic of the CNS axon scaffold in the fly ventral nerve cord. The axons form a ladder-like pattern. The Robo repulsive receptor is only found in the longitudinal portions of CNS axons (arrow). (B) Drosophila embryonic nerve cord stained with an antibody raised against activated vertebrate Caspase-3 that appears to detect Dronc activation in flies [101]. Dying cells are visible as densely stained regions, usually oval in shape (asterisk). A continuous low level of staining can be seen in the region occupied by the longitudinal axons (arrows). This pattern matches the pattern of Robo localization, with the Robo protein excluded from axons segments crossing the midline while upregulated in axons using active Slit/Robo signaling to avoid the midline [102], suggesting that the Robo and caspase activation pathways may be linked. 
If axon repellents activate caspases at low levels, they could mediate contact inhibition or increase sensitivity to survival factors in tumors. Alternatively, it could be that cytoskeletal rearrangements in response to both positive and negative cues require caspase activation, or that caspase activation controls growth cone protein levels [16].

\section{Caspase Signaling at the Fly CNS Midline}

In fly Net $A B$ mutants, most growth cones orient towards the CNS midline but many fail to cross it [103]. The original interpretation of this observation is that Netrins are required for axons to extend across the midline, rather than to attract axons to the midline. The ability of caspase inhibition to rescue axon crossing in $N e t A B$ mutants suggests that caspase activity inhibits midline crossing or axon outgrowth in general. To explain this observation, we propose that there is a low level of caspase activity in the growth cone that needs to be overcome for forward growth. Alternatively, or in parallel, strict temporal control of caspase activation may allow for the necessary cytoskeletal rearrangements [35]. While many axons do not, a significant number of axons do cross the midline in Net $A B$ mutants, revealing that there are undiscovered attractants expressed at the midline. This suggests that caspase inhibition may increase axon outgrowth enough to allow growth cones to use these other cues to locate and grow towards the midline. Interestingly, the fly CNS midline is a source of other neurotrophic factors like the Drosophila neurotrophins DNTs [104], acting through neuronal Toll receptors [31]. Classically, the axonal target tissue produces these neurotrophic factors. An increasing number of examples are now known where intermediate targets supply neurotrophic factors-a phenomenon termed en passant or pre-target neurotrophic action [54,105-107]. As NetB and DNTs are expressed by the CNS midline intermediate targets, and required for motor axon targeting $[95,108]$, both gene families may function as en passant neurotrophic factors and as guidance cues. Interestingly, midline glia require the axon derived epidermal growth factor Spitz to survive, and when the axons fail to contact the midline glia in commissureless mutants, the midline glia migrate to the axons to obtain Spitz [109]. Artificially promoting survival by increasing MAPK signaling, which inhibits Hid, removes the necessity for migration suggesting that Spitz is acting as a caspase-mediated attractive signal. Searching for survival factors could be a general mechanism that influences cell and growth cone migration. MAPK signaling in vertebrate growth cones and commissural axons has been implicated in the response to Netrin supporting this model [16,50]. Neurotrophic factors appear to be required for axon growth independent of their role in cell survival [110], and could do so by inhibiting caspase activation in the growth cone. Together, Drosophila axon navigation across the ventral midline suggests that there remains much to be discovered about the functional links between the classical axon guidance problem of midline crossing and caspase signaling.

\section{Apoptotic Signaling in Axon Branching}

As axons extend, particularly as they enter their target tissues, they also branch, with each branch forming its own growth cone. The process of axon branching is also likely regulated by the apoptotic machinery. One of the most dramatic visualizations of caspase activity in axons is in zebrafish retinal ganglion cells [77]. Caspase activation occurs in a dynamic fashion at branchpoints in developing axonal arbors and genetically interacts with Slit/Robo signaling. Interestingly, Slit is proteolytically cleaved into two fragments, Slit-N and Slit-C. Slit-N stimulates axon branching, whereas full length Slit (Slit-FL) inhibits branching [111-113]. Slit-N is neurotrophic [114], and it will be interesting to see whether Slit-FL can directly activate caspases, perhaps via p38 MAPK signaling as suggesting by zebrafish studies [77]. Additionally, activated caspase activity has been observed in the developing auditory brainstem within several segments of navigating axons as well as their terminal branches within targets where it is proposed to limit unnecessary axonal arborization, because inhibition of caspase activity causes axon branches to spread into inappropriate target tissue [18]. Although much less is known about axon branching within targets, caspase activity appears to be an important regulator of not only primary axons but also their terminal branches. Axon branching may be more 
important than primary axon growth for regenerative recovery of connections after injury or disease, as branching from spared axons can be major contributors to restoring circuit function [115].

\section{Critical Experiments for the Activated Caspase Model}

The most important step forward for the proposed model would be to observe asymmetric activation of caspases in growth cones exposed to attractants or repellents. The long axons of zebrafish retinal ganglion cells have been used to successfully demonstrate localized caspase activity using the SCAT3 probe [77]. It seems likely that the same approach could be used in the growth cones of cultured neurons, as asymmetric gradients of phosphorylated Shootin1 (a cytoplasmic axon outgrowth protein) have been observed in growth cones responding to shallow Netrin gradients [116]. Antibodies against activated (cleaved) caspases do not appear to have sufficient sensitivity at present. If Diap1 levels are modulated in response to guidance cues, as seems likely, using split fluorescent protein strategies to tag the endogenous protein and limiting fluorescence to small subsets of neurons may prove invaluable for in vivo analysis [117]. Both cell culture and in vivo approaches would be especially powerful if combined with high-resolution structured illumination microscopy, as has been used for dendritogenesis in Drosophila embryos [118]. A second important step for the model would be to define which components of the apoptotic machinery are used in axon guidance and to demonstrate genetic interactions with specific signaling pathways, as has been done for axon degeneration and pruning [119]. A technical problem will be to limit cell death in mutant combinations as this could greatly hinder the interpretation of phenotypes. Dose-sensitive genetic interactions will likely allow sensitization of the cell death machinery without triggering apoptosis. For example, Diap1 heterozygotes would be predicted to increase caspase activity and enhance NetAB axon phenotypes without preventing analysis of axon guidance. Positive results in the proposed experiments would establish the basic model. We also propose that accumulating levels of caspase activation by axon errors will eventually reach the threshold to trigger apoptosis. This model requires an integration system to add up the errors over time, with the simplest mechanism being the accumulation of active caspases. Demonstrating that caspase activation persists and accumulates would require in vivo imaging. The Apoliner caspase reporter in which caspase cleavage results in nuclear translocation of enhanced green fluorescent protein (eGFP) while leaving monomeric red fluorescent protein (mRFP) at the cell membrane could function in this approach [120]. For example, mis-navigating eagle commissural axons in NetAB mutants would be predicted to have higher levels of eGFP in the nucleus than those that had successfully crossed the midline. A simpler and potentially complementary approach not requiring live imaging would be to use the CD8::Parp::Venus reporter to demonstrate higher levels of caspase activation in the axons of mis-navigating axons [48]. Additional reporters of caspase activity could similarly be employed [121].

\section{Conclusions}

The neurotrophic hypothesis proposes that competition between neurons for functional connections leads to the correct wiring of the nervous system. Studies of caspases now suggest that the apoptotic machinery plays an active role in forming the connections in the first place. Based on Drosophila studies, we propose that there is a continuous low level of basal caspase activation in growth cones that is kept in check by the caspase inhibitor Diap1. Modulation of caspase activity by external signals affects axon growth rates and allows for the integration of multiple, potentially conflicting, inputs to generate a coherent response. These conclusions are summarized:

Highlights of apoptotic signaling in axon guidance

- Localized activation of caspases in the growth cone may modulate axon guidance.

- Axon attractants can promote cell survival, while repellents can promote cell death.

- Neurotrophic factor effects on axon guidance could be through caspase signaling. 
- Based on an analogy with systems in which caspase signaling has non-apoptotic roles, we propose that the duration and intensity of caspase activation can modulate growth cone activity, while longer and stronger caspase activity can induce death.

- Crossing the CNS midline is associated with lower caspase activity.

- Correct wiring of the nervous system could result from the elimination of incorrectly navigating neurons due to increased activity of the cell death machinery.

Author Contributions: Writing—original draft preparation: T.K.; Writing—review and editing: L.M.H., R.K., G.S.M., and T.K.

Funding: This work was supported by grants from the National Institutes of Health (P20 GM103554 to T.K.), (EY025205 to G.S.M.) and the National Science Foundation (IOS-1053555 to T.K.).

Acknowledgments: We thank Chaye Propst for preparing the original Adobe Illustrator files used to generate Figure 2 and Gunnar Newquist for the image in Figure 1B. We thank members of the Kidd laboratory for discussing ideas.

Conflicts of Interest: The authors declare no conflict of interest.

\section{References}

1. Lowery, L.A.; Van Vactor, D. The trip of the tip: Understanding the growth cone machinery. Nat. Rev. Mol. Cell Biol. 2009, 10, 332-343. [CrossRef] [PubMed]

2. Kolodkin, A.L.; Tessier-Lavigne, M. Mechanisms and molecules of neuronal wiring: A primer. Cold Spring Harbor Perspect. Biol. 2011, 3. [CrossRef] [PubMed]

3. Dent, E.W.; Gupton, S.L.; Gertler, F.B. The growth cone cytoskeleton in axon outgrowth and guidance. Cold Spring Harbor Perspect. Biol. 2011, 3. [CrossRef] [PubMed]

4. Gomez, T.M.; Letourneau, P.C. Actin dynamics in growth cone motility and navigation. J. Neurochem. 2014, 129, 221-234. [CrossRef] [PubMed]

5. Chacon, M.R.; Fazzari, P. FAK: Dynamic integration of guidance signals at the growth cone. Cell Adhes. Migr. 2011, 5, 52-55. [CrossRef]

6. Dudanova, I.; Klein, R. Integration of guidance cues: Parallel signaling and crosstalk. Trends Neurosci. 2013, 36, 295-304. [CrossRef] [PubMed]

7. Varadarajan, S.G.; Kong, J.H.; Phan, K.D.; Kao, T.J; Panaitof, S.C.; Cardin, J.; Eltzschig, H.; Kania, A.; Novitch, B.G.; Butler, S.J. Netrin1 Produced by Neural Progenitors, Not Floor Plate Cells, Is Required for Axon Guidance in the Spinal Cord. Neuron 2017, 94, 790-799. [CrossRef] [PubMed]

8. Dominici, C.; Moreno-Bravo, J.A.; Puiggros, S.R.; Rappeneau, Q.; Rama, N.; Vieugue, P.; Bernet, A.; Mehlen, P.; Chedotal, A. Floor-plate-derived netrin-1 is dispensable for commissural axon guidance. Nature 2017, 545, 350-354. [CrossRef] [PubMed]

9. Tang, X.; Wadsworth, W.G. SAX-3 (Robo) and UNC-40 (DCC) regulate a directional bias for axon guidance in response to multiple extracellular cues. PLoS ONE 2014, 9, e110031. [CrossRef] [PubMed]

10. Stoeckli, E.T. Understanding axon guidance: Are we nearly there yet? Development 2018, 145. [CrossRef] [PubMed]

11. Goodhill, G.J. Can Molecular Gradients Wire the Brain? Trends Neurosci. 2016, 39, 202-211. [CrossRef] [PubMed]

12. Sun, K.L.W.; Correia, J.P.; Kennedy, T.E. Netrins: Versatile extracellular cues with diverse functions. Development 2011, 138, 2153-2169. [CrossRef] [PubMed]

13. Harris, R.; Sabatelli, L.M.; Seeger, M.A. Guidance cues at the Drosophila CNS midline: Identification and characterization of two Drosophila Netrin/UNC-6 homologs. Neuron 1996, 17, 217-228. [CrossRef]

14. Mitchell, K.J.; Doyle, J.L.; Serafini, T.; Kennedy, T.E.; Tessier-Lavigne, M.; Goodman, C.S.; Dickson, B.J. Genetic analysis of Netrin genes in Drosophila: Netrins guide CNS commissural axons and peripheral motor axons. Neuron 1996, 17, 203-215. [CrossRef]

15. Newquist, G.; Drennan, J.M.; Lamanuzzi, M.; Walker, K.; Clemens, J.C.; Kidd, T. Blocking apoptotic signaling rescues axon guidance in Netrin mutants. Cell Rep. 2013, 3, 595-606. [CrossRef] [PubMed]

16. Campbell, D.S.; Holt, C.E. Apoptotic pathway and MAPKs differentially regulate chemotropic responses of retinal growth cones. Neuron 2003, 37, 939-952. [CrossRef] 
17. Ohsawa, S.; Hamada, S.; Asou, H.; Kuida, K.; Uchiyama, Y.; Yoshida, H.; Miura, M. Caspase-9 activation revealed by semaphorin 7A cleavage is independent of apoptosis in the aged olfactory bulb. J. Neurosci. 2009, 29, 11385-11392. [CrossRef] [PubMed]

18. Rotschafer, S.E.; Allen-Sharpley, M.R.; Cramer, K.S. Axonal Cleaved Caspase-3 Regulates Axon Targeting and Morphogenesis in the Developing Auditory Brainstem. Front. Neural Circuits 2016, 10, 84. [CrossRef] [PubMed]

19. Forsthoefel, D.J.; Liebl, E.C.; Kolodziej, P.A.; Seeger, M.A. The Abelson tyrosine kinase, the Trio GEF and Enabled interact with the Netrin receptor Frazzled in Drosophila. Development 2005, 132, 1983-1994. [CrossRef] [PubMed]

20. O'Donnell, M.P.; Bashaw, G.J. Distinct functional domains of the Abelson tyrosine kinase control axon guidance responses to Netrin and Slit to regulate the assembly of neural circuits. Development 2013, 140, 2724-2733. [CrossRef] [PubMed]

21. Dorsten, J.N.; Varughese, B.E.; Karmo, S.; Seeger, M.A.; VanBerkum, M.F. In the absence of frazzled over-expression of Abelson tyrosine kinase disrupts commissure formation and causes axons to leave the embryonic CNS. PLoS ONE 2010, 5, e9822. [CrossRef] [PubMed]

22. Muda, M.; Worby, C.A.; Simonson-Leff, N.; Clemens, J.C.; Dixon, J.E. Use of double-stranded RNA-mediated interference to determine the substrates of protein tyrosine kinases and phosphatases. Biochem. J. 2002, 366, 73-77. [CrossRef] [PubMed]

23. Schmucker, D.; Clemens, J.C.; Shu, H.; Worby, C.A.; Xiao, J.; Muda, M.; Dixon, J.E.; Zipursky, S.L. Drosophila Dscam is an axon guidance receptor exhibiting extraordinary molecular diversity. Cell 2000, 101, 671-684. [CrossRef]

24. Sterne, G.R.; Kim, J.H.; Ye, B. Dysregulated Dscam levels act through Abelson tyrosine kinase to enlarge presynaptic arbors. eLife 2015, 4, e05196. [CrossRef] [PubMed]

25. Worby, C.A.; Simonson-Leff, N.; Clemens, J.C.; Huddler, D., Jr.; Muda, M.; Dixon, J.E. Drosophila Ack targets its substrate, the sorting nexin DSH3PX1, to a protein complex involved in axonal guidance. J. Biol. Chem. 2002, 277, 9422-9428. [CrossRef] [PubMed]

26. Schoenherr, J.A.; Drennan, J.M.; Martinez, J.S.; Chikka, M.R.; Hall, M.C.; Chang, H.C.; Clemens, J.C. Drosophila activated Cdc42 kinase has an anti-apoptotic function. PLoS Genet. 2012, 8, e1002725. [CrossRef] [PubMed]

27. Fuchs, Y.; Steller, H. Programmed cell death in animal development and disease. Cell 2011, 147, 742-758. [CrossRef] [PubMed]

28. Hamburger, V.; Levi-Montalcini, R. Proliferation, differentiation and degeneration in the spinal ganglia of the chick embryo under normal and experimental conditions. J. Exp. Zool. 1949, 111, 457-501. [CrossRef] [PubMed]

29. Michalak, S.M.; Whitman, M.C.; Park, J.G.; Tischfield, M.A.; Nguyen, E.H.; Engle, E.C. Ocular Motor Nerve Development in the Presence and Absence of Extraocular Muscle. Investig. Ophthalmol. Vis. Sci. 2017, 58, 2388-2396. [CrossRef]

30. Foldi, I.; Anthoney, N.; Harrison, N.; Gangloff, M.; Verstak, B.; Nallasivan, M.P.; AlAhmed, S.; Zhu, B.; Phizacklea, M.; Losada-Perez, M.; et al. Three-tier regulation of cell number plasticity by neurotrophins and Tolls in Drosophila. J. Cell Biol. 2017, 216, 1421-1438. [CrossRef] [PubMed]

31. McIlroy, G.; Foldi, I.; Aurikko, J.; Wentzell, J.S.; Lim, M.A.; Fenton, J.C.; Gay, N.J.; Hidalgo, A. Toll-6 and Toll-7 function as neurotrophin receptors in the Drosophila melanogaster CNS. Nat. Neurosci. 2013, 16, 1248-1256. [CrossRef] [PubMed]

32. Keeler, A.B.; Deppmann, C.D. The evolutionary origins of antagonistic neurotrophin signaling. J. Cell Biol. 2017, 216, 1223-1225. [CrossRef] [PubMed]

33. Ramirez, M.L.G.; Salvesen, G.S. A primer on caspase mechanisms. Semin. Cell Dev. Biol. 2018. [CrossRef] [PubMed]

34. Clavier, A.; Rincheval-Arnold, A.; Colin, J.; Mignotte, B.; Guenal, I. Apoptosis in Drosophila: Which role for mitochondria? Apoptosis 2016, 21, 239-251. [CrossRef] [PubMed]

35. Nakajima, Y.I.; Kuranaga, E. Caspase-dependent non-apoptotic processes in development. Cell Death Differ. 2017, 24, 1422-1430. [CrossRef] [PubMed]

36. Hay, B.A.; Wassarman, D.A.; Rubin, G.M. Drosophila homologs of baculovirus inhibitor of apoptosis proteins function to block cell death. Cell 1995, 83, 1253-1262. [CrossRef] 
37. Hay, B.A.; Wolff, T.; Rubin, G.M. Expression of baculovirus P35 prevents cell death in Drosophila. Development 1994, 120, 2121-2129. [PubMed]

38. Quinn, L.; Coombe, M.; Mills, K.; Daish, T.; Colussi, P.; Kumar, S.; Richardson, H. Buffy, a Drosophila Bcl-2 protein, has anti-apoptotic and cell cycle inhibitory functions. EMBO J. 2003, 22, 3568-3579. [CrossRef] [PubMed]

39. Jones, G.; Jones, D.; Zhou, L.; Steller, H.; Chu, Y. Deterin, a new inhibitor of apoptosis from Drosophila melanogaster. J. Biol. Chem. 2000, 275, 22157-22165. [CrossRef] [PubMed]

40. Vernooy, S.Y.; Chow, V.; Su, J.; Verbrugghe, K.; Yang, J.; Cole, S.; Olson, M.R.; Hay, B.A. Drosophila Bruce can potently suppress Rpr- and Grim-dependent but not Hid-dependent cell death. Curr. Biol. 2002, 12, 1164-1168. [CrossRef]

41. Bergmann, A. The role of ubiquitylation for the control of cell death in Drosophila. Cell Death Differ. 2010, 17, 61-67. [CrossRef] [PubMed]

42. Kuranaga, E.; Kanuka, H.; Tonoki, A.; Takemoto, K.; Tomioka, T.; Kobayashi, M.; Hayashi, S.; Miura, M. Drosophila IKK-related kinase regulates nonapoptotic function of caspases via degradation of IAPs. Cell 2006, 126, 583-596. [CrossRef] [PubMed]

43. Muro, I.; Hay, B.A.; Clem, R.J. The Drosophila DIAP1 protein is required to prevent accumulation of a continuously generated, processed form of the apical caspase DRONC. J. Biol. Chem. 2002, 277, 49644-49650. [CrossRef] [PubMed]

44. Arama, E.; Agapite, J.; Steller, H. Caspase activity and a specific cytochrome C are required for sperm differentiation in Drosophila. Dev. Cell 2003, 4, 687-697. [CrossRef]

45. Huh, J.R.; Vernooy, S.Y.; Yu, H.; Yan, N.; Shi, Y.; Guo, M.; Hay, B.A. Multiple apoptotic caspase cascades are required in nonapoptotic roles for Drosophila spermatid individualization. PLoS Biol. 2004, 2 , E15. [CrossRef] [PubMed]

46. Kanuka, H.; Kuranaga, E.; Takemoto, K.; Hiratou, T.; Okano, H.; Miura, M. Drosophila caspase transduces Shaggy/GSK-3beta kinase activity in neural precursor development. EMBO J. 2005, 24, 3793-3806. [CrossRef] [PubMed]

47. Kuo, C.T.; Zhu, S.; Younger, S.; Jan, L.Y.; Jan, Y.N. Identification of E2/E3 ubiquitinating enzymes and caspase activity regulating Drosophila sensory neuron dendrite pruning. Neuron 2006, 51, 283-290. [CrossRef] [PubMed]

48. Williams, D.W.; Kondo, S.; Krzyzanowska, A.; Hiromi, Y.; Truman, J.W. Local caspase activity directs engulfment of dendrites during pruning. Nat. Neurosci. 2006, 9, 1234-1236. [CrossRef] [PubMed]

49. Hong, K.; Hinck, L.; Nishiyama, M.; Poo, M.M.; Tessier-Lavigne, M.; Stein, E. A ligand-gated association between cytoplasmic domains of UNC5 and DCC family receptors converts netrin-induced growth cone attraction to repulsion. Cell 1999, 97, 927-941. [CrossRef]

50. Forcet, C.; Ye, X.; Granger, L.; Corset, V.; Shin, H.; Bredesen, D.E.; Mehlen, P. The dependence receptor DCC (deleted in colorectal cancer) defines an alternative mechanism for caspase activation. Proc. Natl. Acad. Sci. USA 2001, 98, 3416-3421. [CrossRef] [PubMed]

51. Mehlen, P.; Rabizadeh, S.; Snipas, S.J.; Assa-Munt, N.; Salvesen, G.S.; Bredesen, D.E. The DCC gene product induces apoptosis by a mechanism requiring receptor proteolysis. Nature 1998, 395, 801-804. [CrossRef] [PubMed]

52. Castets, M.; Broutier, L.; Molin, Y.; Brevet, M.; Chazot, G.; Gadot, N.; Paquet, A.; Mazelin, L.; Jarrosson-Wuilleme, L.; Scoazec, J.Y.; et al. DCC constrains tumour progression via its dependence receptor activity. Nature 2012, 482, 534-537. [CrossRef] [PubMed]

53. Williams, M.E.; Lu, X.; McKenna, W.L.; Washington, R.; Boyette, A.; Strickland, P.; Dillon, A.; Kaprielian, Z.; Tessier-Lavigne, M.; Hinck, L. UNC5A promotes neuronal apoptosis during spinal cord development independent of netrin-1. Nat. Neurosci. 2006, 9, 996-998. [CrossRef] [PubMed]

54. Furne, C.; Rama, N.; Corset, V.; Chedotal, A.; Mehlen, P. Netrin-1 is a survival factor during commissural neuron navigation. Proc. Natl. Acad. Sci. USA 2008, 105, 14465-14470. [CrossRef] [PubMed]

55. Bin, J.M.; Han, D.; Lai Wing Sun, K.; Croteau, L.P.; Dumontier, E.; Cloutier, J.F.; Kania, A.; Kennedy, T.E. Complete Loss of Netrin-1 Results in Embryonic Lethality and Severe Axon Guidance Defects without Increased Neural Cell Death. Cell Rep. 2015, 12, 1099-1106. [CrossRef] [PubMed]

56. Neuhaus-Follini, A.; Bashaw, G.J. The Intracellular Domain of the Frazzled/DCC Receptor Is a Transcription Factor Required for Commissural Axon Guidance. Neuron 2015, 87, 751-763. [CrossRef] [PubMed] 
57. VanZomeren-Dohm, A.; Sarro, J.; Flannery, E.; Duman-Scheel, M. The Drosophila Netrin receptor frazzled/DCC functions as an invasive tumor suppressor. BMC Dev. Biol. 2011, 11, 41. [CrossRef] [PubMed]

58. Igarashi, Y.; Eroshkin, A.; Gramatikova, S.; Gramatikoff, K.; Zhang, Y.; Smith, J.W.; Osterman, A.L.; Godzik, A. CutDB: A proteolytic event database. Nucleic Acids Res. 2007, 35, D546-D549. [CrossRef] [PubMed]

59. Crawford, E.D.; Seaman, J.E.; Agard, N.; Hsu, G.W.; Julien, O.; Mahrus, S.; Nguyen, H.; Shimbo, K.; Yoshihara, H.A.; Zhuang, M.; et al. The DegraBase: A database of proteolysis in healthy and apoptotic human cells. Mol. Cell. Proteom. 2013, 12, 813-824. [CrossRef] [PubMed]

60. Luthi, A.U.; Martin, S.J. The CASBAH: A searchable database of caspase substrates. Cell Death Differ. 2007, 14, $641-650$. [CrossRef] [PubMed]

61. Mashima, T.; Naito, M.; Noguchi, K.; Miller, D.K.; Nicholson, D.W.; Tsuruo, T. Actin cleavage by CPP-32/apopain during the development of apoptosis. Oncogene 1997, 14, 1007-1012. [CrossRef] [PubMed]

62. Westphal, D.; Sytnyk, V.; Schachner, M.; Leshchyns'ka, I. Clustering of the neural cell adhesion molecule (NCAM) at the neuronal cell surface induces caspase-8- and -3-dependent changes of the spectrin meshwork required for NCAM-mediated neurite outgrowth. J. Biol. Chem. 2010, 285, 42046-42057. [CrossRef] [PubMed]

63. Martin, D.N.; Baehrecke, E.H. Caspases function in autophagic programmed cell death in Drosophila. Development 2004, 131, 275-284. [CrossRef] [PubMed]

64. Akhter, A.; Caution, K.; Abu Khweek, A.; Tazi, M.; Abdulrahman, B.A.; Abdelaziz, D.H.; Voss, O.H.; Doseff, A.I.; Hassan, H.; Azad, A.K.; et al. Caspase-11 promotes the fusion of phagosomes harboring pathogenic bacteria with lysosomes by modulating actin polymerization. Immunity 2012, 37, 35-47. [CrossRef] [PubMed]

65. Li, J.; Brieher, W.M.; Scimone, M.L.; Kang, S.J.; Zhu, H.; Yin, H.; von Andrian, U.H.; Mitchison, T.; Yuan, J. Caspase-11 regulates cell migration by promoting Aip1-Cofilin-mediated actin depolymerization. Nat. Cell Biol. 2007, 9, 276-286. [CrossRef] [PubMed]

66. Han, M.H.; Jiao, S.; Jia, J.M.; Chen, Y.; Chen, C.Y.; Gucek, M.; Markey, S.P.; Li, Z. The novel caspase-3 substrate Gap43 is involved in AMPA receptor endocytosis and long-term depression. Mol. Cell. Proteom. 2013, 12, 3719-3731. [CrossRef] [PubMed]

67. Geisbrecht, E.R.; Montell, D.J. A role for Drosophila IAP1-mediated caspase inhibition in Rac-dependent cell migration. Cell 2004, 118, 111-125. [CrossRef] [PubMed]

68. Koto, A.; Kuranaga, E.; Miura, M. Temporal regulation of Drosophila IAP1 determines caspase functions in sensory organ development. J. Cell Biol. 2009, 187, 219-231. [CrossRef] [PubMed]

69. Oshima, K.; Takeda, M.; Kuranaga, E.; Ueda, R.; Aigaki, T.; Miura, M.; Hayashi, S. IKK epsilon regulates F actin assembly and interacts with Drosophila IAP1 in cellular morphogenesis. Curr. Biol. 2006, 16, 1531-1537. [CrossRef] [PubMed]

70. Perez-Garijo, A.; Shlevkov, E.; Morata, G. The role of Dpp and Wg in compensatory proliferation and in the formation of hyperplastic overgrowths caused by apoptotic cells in the Drosophila wing disc. Development 2009, 136, 1169-1177. [CrossRef] [PubMed]

71. Rudrapatna, V.A.; Bangi, E.; Cagan, R.L. Caspase signalling in the absence of apoptosis drives Jnk-dependent invasion. EMBO Rep. 2013, 14, 172-177. [CrossRef] [PubMed]

72. Portela, M.; Richardson, H.E. Death takes a holiday-Non-apoptotic role for caspases in cell migration and invasion. EMBO Rep. 2013, 14, 107-108. [CrossRef] [PubMed]

73. Goldberg, J.L.; Espinosa, J.S.; Xu, Y.; Davidson, N.; Kovacs, G.T.; Barres, B.A. Retinal ganglion cells do not extend axons by default: Promotion by neurotrophic signaling and electrical activity. Neuron 2002, 33, 689-702. [CrossRef]

74. Lentz, S.I.; Knudson, C.M.; Korsmeyer, S.J.; Snider, W.D. Neurotrophins support the development of diverse sensory axon morphologies. J. Neurosci. 1999, 19, 1038-1048. [CrossRef] [PubMed]

75. Yang, J.Y.; Michod, D.; Walicki, J.; Murphy, B.M.; Kasibhatla, S.; Martin, S.J.; Widmann, C. Partial cleavage of RasGAP by caspases is required for cell survival in mild stress conditions. Mol. Cell. Biol. 2004, 24, 10425-10436. [CrossRef] [PubMed]

76. Gilman, C.P.; Mattson, M.P. Do apoptotic mechanisms regulate synaptic plasticity and growth-cone motility? Neuromol. Med. 2002, 2, 197-214. [CrossRef]

77. Campbell, D.S.; Okamoto, H. Local caspase activation interacts with Slit-Robo signaling to restrict axonal arborization. J. Cell Biol. 2013, 203, 657-672. [CrossRef] [PubMed]

78. Igaki, T.; Yamamoto-Goto, Y.; Tokushige, N.; Kanda, H.; Miura, M. Down-regulation of DIAP1 triggers a novel Drosophila cell death pathway mediated by Dark and DRONC. J. Biol. Chem. 2002, 277, 23103-23106. [CrossRef] [PubMed] 
79. Muro, I.; Means, J.C.; Clem, R.J. Cleavage of the apoptosis inhibitor DIAP1 by the apical caspase DRONC in both normal and apoptotic Drosophila cells. J. Biol. Chem. 2005, 280, 18683-18688. [CrossRef] [PubMed]

80. Rodriguez, A.; Chen, P.; Oliver, H.; Abrams, J.M. Unrestrained caspase-dependent cell death caused by loss of Diap1 function requires the Drosophila Apaf-1 homolog, Dark. EMBO J. 2002, 21, 2189-2197. [CrossRef] [PubMed]

81. Zimmermann, K.C.; Ricci, J.E.; Droin, N.M.; Green, D.R. The role of ARK in stress-induced apoptosis in Drosophila cells. J. Cell Biol. 2002, 156, 1077-1087. [CrossRef] [PubMed]

82. Wright, K.M.; Linhoff, M.W.; Potts, P.R.; Deshmukh, M. Decreased apoptosome activity with neuronal differentiation sets the threshold for strict IAP regulation of apoptosis. J. Cell Biol. 2004, 167, 303-313. [CrossRef] [PubMed]

83. Erturk, A.; Wang, Y.; Sheng, M. Local pruning of dendrites and spines by caspase-3-dependent and proteasome-limited mechanisms. J. Neurosci. 2014, 34, 1672-1688. [CrossRef] [PubMed]

84. Hollville, E.; Deshmukh, M. Physiological functions of non-apoptotic caspase activity in the nervous system. Semin. Cell Dev. Biol. 2017. [CrossRef] [PubMed]

85. Mehlen, P.; Delloye-Bourgeois, C.; Chedotal, A. Novel roles for Slits and netrins: Axon guidance cues as anticancer targets? Nat. Rev. Cancer 2011, 11, 188-197. [CrossRef] [PubMed]

86. Gara, R.K.; Kumari, S.; Ganju, A.; Yallapu, M.M.; Jaggi, M.; Chauhan, S.C. Slit/Robo pathway: A promising therapeutic target for cancer. Drug Discov. Today 2015, 20, 156-164. [CrossRef] [PubMed]

87. Colin, J.; Garibal, J.; Clavier, A.; Szuplewski, S.; Risler, Y.; Milet, C.; Gaumer, S.; Guenal, I.; Mignotte, B. Screening of suppressors of bax-induced cell death identifies glycerophosphate oxidase- 1 as a mediator of debcl-induced apoptosis in Drosophila. Genes Cancer 2015, 6, 241-253. [CrossRef] [PubMed]

88. Manhire-Heath, R.; Golenkina, S.; Saint, R.; Murray, M.J. Netrin-dependent downregulation of Frazzled/DCC is required for the dissociation of the peripodial epithelium in Drosophila. Nat. Commun. 2013, 4, 2790. [CrossRef] [PubMed]

89. Vaughen, J.; Igaki, T. Slit-Robo Repulsive Signaling Extrudes Tumorigenic Cells from Epithelia. Dev. Cell 2016, 39, 683-695. [CrossRef] [PubMed]

90. Ben-Zvi, A.; Manor, O.; Schachner, M.; Yaron, A.; Tessier-Lavigne, M.; Behar, O. The Semaphorin receptor PlexinA3 mediates neuronal apoptosis during dorsal root ganglia development. J. Neurosci. 2008, 28, 12427-12432. [CrossRef] [PubMed]

91. Wehner, A.B.; Abdesselem, H.; Dickendesher, T.L.; Imai, F.; Yoshida, Y.; Giger, R.J.; Pierchala, B.A. Semaphorin 3A is a retrograde cell death signal in developing sympathetic neurons. Development 2016, 143, 1560-1570. [CrossRef] [PubMed]

92. Lee, H.; Park, S.; Kang, Y.S.; Park, S. EphA receptors form a complex with caspase-8 to induce apoptotic cell death. Mol. Cells 2015, 38, 349-355. [CrossRef] [PubMed]

93. Zhang, X.; Li, J.; Liu, J.; Luo, H.; Gou, K.; Cui, S. Prostaglandin F2alpha upregulates Slit/Robo expression in mouse corpus luteum during luteolysis. J. Endocrinol. 2013, 218, 299-310. [CrossRef] [PubMed]

94. Dickinson, R.E.; Fegan, K.S.; Ren, X.; Hillier, S.G.; Duncan, W.C. Glucocorticoid regulation of SLIT/ROBO tumour suppressor genes in the ovarian surface epithelium and ovarian cancer cells. PLoS ONE 2011, 6, e27792. [CrossRef] [PubMed]

95. Winberg, M.L.; Mitchell, K.J.; Goodman, C.S. Genetic analysis of the mechanisms controlling target selection: Complementary and combinatorial functions of netrins, semaphorins, and IgCAMs. Cell 1998, 93, 581-591. [CrossRef]

96. Jiao, S.; Li, Z. Nonapoptotic function of BAD and BAX in long-term depression of synaptic transmission. Neuron 2011, 70, 758-772. [CrossRef] [PubMed]

97. Gu, Z.; Serradj, N.; Ueno, M.; Liang, M.; Li, J.; Baccei, M.L.; Martin, J.H.; Yoshida, Y. Skilled Movements Require Non-apoptotic Bax/Bak Pathway-Mediated Corticospinal Circuit Reorganization. Neuron 2017, 94, 626-641. [CrossRef] [PubMed]

98. Williams, D.W.; Truman, J.W. Cellular mechanisms of dendrite pruning in Drosophila: Insights from in vivo time-lapse of remodeling dendritic arborizing sensory neurons. Development 2005, 132, 3631-3642. [CrossRef] [PubMed]

99. Rogulja-Ortmann, A.; Luer, K.; Seibert, J.; Rickert, C.; Technau, G.M. Programmed cell death in the embryonic central nervous system of Drosophila melanogaster. Development 2007, 134, 105-116. [CrossRef] [PubMed] 
100. Mukherjee, A.; Williams, D.W. More alive than dead: Non-apoptotic roles for caspases in neuronal development, plasticity and disease. Cell Death Differ. 2017, 24, 1411-1421. [CrossRef] [PubMed]

101. Fan, Y.; Bergmann, A. The cleaved-Caspase-3 antibody is a marker of Caspase-9-like DRONC activity in Drosophila. Cell Death Differ. 2010, 17, 534-539. [CrossRef] [PubMed]

102. Kidd, T.; Brose, K.; Mitchell, K.J.; Fetter, R.D.; Tessier-Lavigne, M.; Goodman, C.S.; Tear, G. Roundabout controls axon crossing of the CNS midline and defines a novel subfamily of evolutionarily conserved guidance receptors. Cell 1998, 92, 205-215. [CrossRef]

103. Brankatschk, M.; Dickson, B.J. Netrins guide Drosophila commissural axons at short range. Nat. Neurosci. 2006, 9, 188-194. [CrossRef] [PubMed]

104. Zhu, B.; Pennack, J.A.; McQuilton, P.; Forero, M.G.; Mizuguchi, K.; Sutcliffe, B.; Gu, C.J.; Fenton, J.C.; Hidalgo, A. Drosophila neurotrophins reveal a common mechanism for nervous system formation. PLoS Biol. 2008, 6, e284. [CrossRef] [PubMed]

105. Wang, H.; Tessier-Lavigne, M. En passant neurotrophic action of an intermediate axonal target in the developing mammalian CNS. Nature 1999, 401, 765-769. [CrossRef] [PubMed]

106. Usui, N.; Watanabe, K.; Ono, K.; Tomita, K.; Tamamaki, N.; Ikenaka, K.; Takebayashi, H. Role of motoneuron-derived neurotrophin 3 in survival and axonal projection of sensory neurons during neural circuit formation. Development 2012, 139, 1125-1132. [CrossRef] [PubMed]

107. Kuruvilla, R.; Zweifel, L.S.; Glebova, N.O.; Lonze, B.E.; Valdez, G.; Ye, H.; Ginty, D.D. A neurotrophin signaling cascade coordinates sympathetic neuron development through differential control of TrkA trafficking and retrograde signaling. Cell 2004, 118, 243-255. [CrossRef] [PubMed]

108. Sutcliffe, B.; Forero, M.G.; Zhu, B.; Robinson, I.M.; Hidalgo, A. Neuron-type specific functions of DNT1, DNT2 and Spz at the Drosophila neuromuscular junction. PLoS ONE 2013, 8, e75902. [CrossRef] [PubMed]

109. Bergmann, A.; Tugentman, M.; Shilo, B.Z.; Steller, H. Regulation of cell number by MAPK-dependent control of apoptosis: A mechanism for trophic survival signaling. Dev. Cell 2002, 2, 159-170. [CrossRef]

110. Goldberg, J.L. How does an axon grow? Genes Dev. 2003, 17, 941-958. [CrossRef] [PubMed]

111. Wang, K.H.; Brose, K.; Arnott, D.; Kidd, T.; Goodman, C.S.; Henzel, W.; Tessier-Lavigne, M. Biochemical purification of a mammalian slit protein as a positive regulator of sensory axon elongation and branching. Cell 1999, 96, 771-784. [CrossRef]

112. Nguyen Ba-Charvet, K.T.; Brose, K.; Ma, L.; Wang, K.H.; Marillat, V.; Sotelo, C.; Tessier-Lavigne, M.; Chedotal, A. Diversity and specificity of actions of Slit2 proteolytic fragments in axon guidance. J. Neurosci. 2001, 21, 4281-4289. [CrossRef] [PubMed]

113. Dascenco, D.; Erfurth, M.-L.; Izadifar, A.; Song, M.; Sachse, S.; Bortnick, R.; Urwyler, O.; Petrovic, M.; Ayaz, D.; He, H.; et al. Slit and Receptor Tyrosine Phosphatase 69D Confer Spatial Specificity to Axon Branching via Dscam1. Cell 2015. [CrossRef] [PubMed]

114. Piper, M.; Nurcombe, V.; Reid, K.; Bartlett, P.; Little, M. N-terminal Slit2 promotes survival and neurite extension in cultured peripheral neurons. Neuroreport 2002, 13, 2375-2378. [CrossRef] [PubMed]

115. Chen, M.; Zheng, B. Axon plasticity in the mammalian central nervous system after injury. Trends Neurosci. 2014, 37, 583-593. [CrossRef] [PubMed]

116. Baba, K.; Yoshida, W.; Toriyama, M.; Shimada, T.; Manning, C.F.; Saito, M.; Kohno, K.; Trimmer, J.S.; Watanabe, R.; Inagaki, N. Gradient-reading and mechano-effector machinery for netrin-1-induced axon guidance. eLife 2018, 7. [CrossRef] [PubMed]

117. Kamiyama, D.; Sekine, S.; Barsi-Rhyne, B.; Hu, J.; Chen, B.; Gilbert, L.A.; Ishikawa, H.; Leonetti, M.D.; Marshall, W.F.; Weissman, J.S.; et al. Versatile protein tagging in cells with split fluorescent protein. Nat. Commun. 2016, 7, 11046. [CrossRef] [PubMed]

118. Kamiyama, D.; McGorty, R.; Kamiyama, R.; Kim, M.D.; Chiba, A.; Huang, B. Specification of Dendritogenesis Site in Drosophila aCC Motoneuron by Membrane Enrichment of Pak1 through Dscam1. Dev. Cell 2015, 35, 93-106. [CrossRef] [PubMed]

119. Geden, M.J.; Deshmukh, M. Axon degeneration: Context defines distinct pathways. Curr. Opin. Neurobiol. 2016, 39, 108-115. [CrossRef] [PubMed] 
120. Bardet, P.L.; Kolahgar, G.; Mynett, A.; Miguel-Aliaga, I.; Briscoe, J.; Meier, P.; Vincent, J.P. A fluorescent reporter of caspase activity for live imaging. Proc. Natl. Acad. Sci. USA 2008, 105, 13901-13905. [CrossRef] [PubMed]

121. Melzer, J.; Broemer, M. Nerve-racking-Apoptotic and non-apoptotic roles of caspases in the nervous system of Drosophila. Eur. J. Neurosci. 2016, 44, 1683-1690. [CrossRef] [PubMed] 